\title{
STATE FINANCES IN POST-COMMUNIST POLAND: BUILDING CAPACITY AND CONSENT
}

\section{Easter Gerald M.}

$\mathrm{PhD}$ Political Science, is Professor of Political Science at Boston College. Address: Department of Political Science, 229 McGuinn Hall, Boston College, Chestnut Hill, MA, 02467, USA.

E-mail: gerald.easter@bc.edu.

\begin{abstract}
In the early 1990s, post-communist state actors struggled for the first time with trying to get people to pay taxes. They sought to create new systems of revenue extraction for their quickly changing transition economies. Their immediate concern in devising means of revenue extraction was to break out of the inherited fiscal constraints of the old regime - weak administrative capacity and narrow revenue base. This required finding accommodation with society. Post-communist states cultivated tax compliance in a variety of ways: some states relied more on consent-based strategies, while others adopted more coercive strategies. Poland developed a distinctively non-coercive approach to building capacity and consent, which enhanced the fiscal capacity of the post-communist state. Poland's strategy of "legalistic consent" as the basis for its new system of revenue extraction proved a smashing success. The fiscal capacity of the post-communist Polish state was sufficiently strengthened to overcome the crippling initial domestic fiscal crisis and to withstand the fiscal shocks of two international financial crises in 1998 and 2008.
\end{abstract}

Keywords: fiscal policy; taxation and tax compliance; Poland.

\section{Defining the parameters: Fiscal capacity and consent under post-communism}

The fall of communism in Poland was a negotiated process in which counterelites eventually took full control of the government from communist elites. When counter-elites came to power, they inherited the existing communist state apparatus more or less intact. The first post-communist government may have fantasized about razing the communist state and unleashing the free market, but once in power it could not simply dismantle the old administrative apparatus. Poland did not experience the same type of fragmentation of the state's bureaucratic-administrative resources as did some other post-communist states. In particular, Poland's system of state finances remained relatively coherent and centralized during the 
1990s. Even though the communist-designed tax administration was woefully illequipped to function in the transition economy, it still managed to collect sufficient revenue to avert fiscal crisis, while undergoing extensive internal reform at the same time.

The Ministry of Finance (MinFin) dominated the revenue extraction process. The ambitious and savvy personalities of several finance ministers - Leszek Balcerowicz, Grzegorz Kolodko, Marek Belka - reinforced the bureaucracy's top position. Tax policy, tax administration, customs agency, fiscal control, and state treasury were subordinated to MinFin (Borodo, 2000, pp. 42-44). Bureaucratic competition occurred among the departments but the all-inclusive organizational scheme kept inter-agency rivalries from causing fiscal dysfunction. The bureaucratic lines of command in state finance were widely recognized and rarely challenged. Within MinFin, revenue extraction was a priority task, as indicated by the "vice minister" status routinely accorded to the undersecretaries for tax collection and fiscal control. State finance also benefited from stability in leading personnel in the revenue extraction process, especially during the social-democratic governments from 1992 to $1998^{1}$.

The new tax administration struggled to locate capital flows in the transition economy. Plans to enhance monitoring capabilities took time to implement. The tax administration was supposed to be fitted with a high-tech information-gathering system, called Poltax. But it was not until 1993, four years after the introduction of radical economic reform, that a network of French-provided computers was installed (Polish News Bulletin 29 January 1993). And, it was not until the next year that MinFin began to assign identification numbers to the country's 20 million taxpayers and to organize a property registry, the main sources of information for the proposed Poltax database (Polish News Bulletin 20 May 1994). The Poltax system was not fully up and running until the final push to join the European Union (EU) in the 2000s. Thus, the state's tax collection was hampered by bureaucratic blind spots, such as the outstanding tax debt of the public sector or the volume of cross-border trade that sidestepped the customs agency (Rzeczpospolita, 13 February 1997, p. 37).

The tax administration was further hampered by narrowly defined powers of investigation and enforcement. Taxpayer bank accounts were off-limits to tax inspectors. This information could only be obtained through special permission from the tax inspector general's office, which itself could not be obtained unless a tax law violation was established. But without access to a complete record of financial assets, tax inspectors had difficulty determining whether violations had occurred. Moreover, tax inspectors could not themselves determine fraud or issue fines, matters that only a court was empowered to decide on. The director of MinFin's Tax Department, Andrzej Zelechowski, however, complained that the courts were too slow and too lenient in dealing with tax cheats (Gazeta Wyborcza, 20 August 1994). The tax inspector was anything but an imposing figure; indeed, just the opposite. Tax inspectors were often refused access to records and shown the door at the businesses they came to audit; tax inspectors and their families were subjected to physical threats; and a Poznan inspector handling a high stakes fraud case was badly beaten on the sidewalk in an attempt to rob him of his brief- 
case. MinFin appealed to the prosecutor general to do something about all this, but the prosecutor's office declined to get involved ${ }^{2}$.

As early as 1993, the finance ministry urged the Sejm to bolster the authority of tax inspectors, but it took three years before the urge became legislation. MinFin proposed to expand the information-gathering powers of inspectors, to allow inspectors to enter the homes of suspected evaders, to limit the number of taxpayer appeals against the claims of the tax administration, and to relieve the tax administration of having to prove "intended guilt" of tax evasion in court cases. ${ }^{3}$ In 1996, the Sejm finally passed legislation to enhance the powers of the tax administration. But this fiscal administrative reform act immediately aroused indignation among taxpayer groups, the mass media, the National Bank, and even the Helsinki Commission. The opposition was especially determined not to give the tax administration the power to access the bank records of taxpayers. The Ombudsman, an official constitutional watchdog agency, said that this measure violated the right to privacy. The Constitutional Tribunal agreed, and struck down this particular provision. Even though tax evasion was on the increase, the greater concern was not to give too much authority to the state's revenue agents. When it came to the administration of tax collection in Poland, institutions were deliberately designed to protect capital from coercion.

The Polish state sought to cultivate societal compliance with its new revenue claims by non-coercive means. In so doing, a new tax regime was built on the basis of "legalistic consent." Legalistic consent is a minimalist form of quasi-voluntary compliance. In principle, Polish society accepted its newly assigned status as taxpayers as well as the state's new revenue claims. In practice, however, Polish society tended to avoid complying in full and contrived a variety of formal means to reduce its tax burden instead. Polish taxpayers big and small readily took advantage of tax law loopholes and legal checks on the state bureaucracy. As a result, the new targets of state tax collection - wage earners and petty capitalists - managed to hang on to a larger share of their wealth, while still paying at least something to the state. It was enough. The Polish state succeeded in establishing new revenue claims and expanding the revenue base, thereby securing the foundations of fiscal capacity. What is most notable about this achievement is that it was done without resort to coercion.

The rules of engagement in the transitional tax regime reinforced the Polish state's compliance strategy of "legalistic consent." The post-communist state did not create a formal framework to define roles and obligations in the new tax regime until the enactment of the 1997 Constitution. However, a working apparatus was left over from the communist regime. These inherited institutional mechanisms, the Ombudsman and the Constitutional Tribunal, acquired unexpected prominence after the fall of the old regime. In the competition for capital in the transitional tax regime, these institutions patrolled the boundary line between state and society, and helped to shape the behavior of each. Most importantly, they constrained the state bureaucracy from acting on arbitrary impulse and from using coercion to compel compliance.

Polish taxpayers were quick to recognize the formal limits on the state's means of extraction and to carve out an informal sphere of acceptable behavior. In gen- 
eral, Polish citizens complied with the state's new revenue claims, to the minimal extent that they were legally obliged to. Taxpayers had several options available, including appeal boards within the tax administration and the independent administrative courts. Taxpayers, especially businessmen, also had society-based organizations to help them with tax disputes along with a blossoming tax-consulting industry. Polish taxpayers took advantage of the legal checks in the collection process by devising strategies to avoid paying their full tax obligations.

The opportunity for corruption, of course, existed in the new tax regime, as it does any place where power and wealth meet. Political contributions and well-placed bribes were informal means by which entrepreneurs dealt with their tax obligations. Still, buying a tax exemption or reduction was consistent with the "legalistic" façade of the transitional tax regime. In one high-profile case in Poznan, local leaders encouraged the business community to help sponsor the underfunded local police force. This market-based solution to local law enforcement, however, caused a national scandal and high office resignations, when it was found that some local businessmen provided police with computers, office equipment, prostitutes, and vodka in exchange for protection against tax inspections (The Guardian, 15 March 1994, p. 9).

The shortcomings of the tax-collection system situation were well known, yet tolerated by the fiscal managers of the post-communist state. From the state's perspective, it was more important to legitimize its new revenue claims, and it did so by getting as many taxpayers as possible into the system. They fought outright evasion, but accommodated widespread avoidance. An anonymous tax inspector summed it up well: "Most businesses cheat, but if you take only 20-30 percent from the Treasury, then you are still a decent taxpayer and inspectors have no time or energy to bother with you" (Polish News Bulletin 12 August 1991). This was the essence of the state's compliance strategy of "legalistic consent" that shaped Poland's new tax regime. Legalistic consent was most notable for not inhibiting the development of new businesses, which enabled the state to expand its revenue base.

\section{Strengthening fiscal capacity by expanding the revenue base}

In charting a path from the fiscal wreck of the old regime, the Polish state stood out among its post-communist peers for successfully expanding the revenue base. At the outset of the transition, Poland's domestic economy did not contain prosperous and easily exploitable income sources. The natural resource base lacked coveted commodities, and the manufacturing sector lagged behind global standards. Its former communist trade partners were no longer compelled to take Polish goods. Beyond the bloc, there was not a lot of profit to be had from coal, canned hams, and outdated industrial stock. What the new Polish state had plenty of was rising debt and falling currency. But as the revenue base expanded, fiscal capacity was strengthened: by decade's end, the Polish state was credit-worthy and zloty-stable.

The Polish state at first teetered at the edge of fiscal abyss (Rosati, 1998, pp. 135-139). Finance Minister Leszek Balcerowicz inherited a desperate financial 
situation, which shock therapy only exacerbated. Emergency fiscal measures were enacted. First, an austerity program targeted budgetary expenses. Social payments and industrial subsidies were slashed, and investment projects suspended for fifteen months. Whereas in 1988, enterprise subsidies accounted for one-third of state budgetary expenditures, in 1990 the figure was reduced by almost a half to 16.9 percent, and in 1991 declined further to 9.4 percent (Belka et al. 1993, p. 24). Second, the unabashedly pro-capitalist government succeeded in securing relief from western creditors for its $\$ 30+$ billion foreign debt, already in default. An informal clique of international financiers, the Paris Club, first agreed to reschedule Poland's debt obligations and later to forgive nearly half of Poland's outstanding foreign debts (OECD, 1992, pp. 30, 31; Wellisz et al., 1993, pp. 29-33). It was both a gesture of goodwill and good business, as the Polish market was opened up to western business ventures. Finally, the currency was devalued. The worth of a Polish zloty was established by making it convertible to the U.S. dollar; the zloty's value quickly slid downward: from 1,400 zloty to one dollar in September 1989 to 9,500 zloty to one dollar in January 1990 (Belka et al., 1993, p, 26).

With the state industrial sector reeling from shock, the government had to locate new revenue sources. Tax reform was one of the priority policy areas of the Balcerowicz team. The existing tax system was an incoherent mess of rates, reductions, and exemptions, mostly negotiated on an individual firm-by-firm basis. In November 1989, Balcerowicz formed a special task force to design a new tax system. In early December, the reformers began meeting in special committee sessions with members of the Sejm and the Senate to work out the details. In the spirit of "extraordinary politics," the process was not especially contentious. In late December, a comprehensive package of eleven macro-reforms was passed by the legislature, including two pieces dealing specifically with taxation: a tax code meant to remove the punitive burden on the private sector and a tax penalty meant to impose a punitive burden on the public sector. The Balcerowicz team designed a tax system that could serve the main goals of shock therapy - the promotion of market capitalism and demolition of command socialism.

Shock therapy was meant to instigate a socio-economic revolution. The new pro-market tax code was intended to facilitate both the growth of capitalism and demise of socialism. By 1992, 3.5 million new jobs were created in the private sector, yet more than 12 million workers still remained in the state sector. The communist state was long accustomed to extracting revenue straight from its industrial sector; the post-communist state recklessly sundered this relationship. The share of central state tax revenue as a percentage of GDP dropped from 28 percent in 1990 to 23 percent in 1991, causing the budget deficit to reach 6 percent of GDP in 1992 (Bratkowski, 1997). The unexpectedly steep revenue drop forced the government back to the familiar state sector. Unlike the emerging private sector, state enterprises were well known to the tax administration, which readily applied the popiwek (tax on excessive wage increases) and dividend taxes, further squeezing the already shrinking real incomes of public employees. (See Table 1.) These taxes were blamed for putting state enterprises in a position of competitive disadvantage in the transition economy. Thus, the unequal tax burden between private and public sectors became a rallying issue to Poland's hard-hit workers. 
Table 1

Tax burden on public/private sectors, $1991, \%$

\begin{tabular}{|l|c|c|}
\hline & Public sector & Private sector \\
\hline Total share of sales & 72 & 28 \\
\hline Total share of taxes & 90 & 10 \\
\hline
\end{tabular}

Source: Glawny Urzad Statystyczny (GUS) (Main Statistical Office), as cited in Crombrugghe \& Lipton, 1994, p. 117.

With state enterprise profits in decline, the government targeted instead the wages of state enterprise employees. The excess wage tax, the popiwek, was supposed to be a fiscal instrument to check inflation, but it quickly became a vital revenue source. In 1990, the popiwek and the dividend taxes together made up 11 percent of the state's total revenue take; in 1991, the figure reached 17 percent (World Economy Research Institute, 1992, Table 8). ${ }^{4}$ Government budget planners originally estimated that the state would collect 3 trillion zloty for the popiwek in 1991, but in November the figure was revised upward to 23 trillion zloty (Ibid., Table 7). Desperate for income, the government gouged state industrial enterprises with onerous taxes. Even liberal economists criticized the government's punishing tax policy. Citing "excessive tax fiscalism" as a principal cause of industrial recession, an editorial in Zycie Gospodarcze, an influential pro-market economic newspaper, complained that "Polish firms in the so-called socialized sector pay the highest taxes in the world" (30 July 1991). (See Table 2.)

Table 2

Tax burden on state industry gross profits (in trillion zloty)

\begin{tabular}{|l|c|c|c|c|}
\hline \multicolumn{1}{|c|}{ Taxes } & $\mathbf{1 9 8 9}$ & $\mathbf{1 9 9 0}$ & $\mathbf{1 9 9 1}$ & $\mathbf{1 9 9 2}$ (I-III Q) \\
\hline Total & $\mathbf{3 8}$ & $\mathbf{5 3 . 2}$ & $\mathbf{1 5 8 . 5}$ & $\mathbf{1 7 6 . 6}$ \\
\hline Corporate & & & & \\
\hline income tax & 31.1 & 37.3 & 77.6 & 96.4 \\
\hline Popiwek & 1.5 & 6.7 & 40.5 & 49.6 \\
\hline Dividend & 5.4 & 9.2 & 40.4 & 49.6 \\
\hline
\end{tabular}

Source: Belka et al., 1993, p. 38.

The political reaction led to the early departure of the free-market government and return of the political left, in the form of reformed and reorganized social democrats. But Balcerowicz had already made an invaluable contribution to the post-communist state, through policies that spurred an onrush of private enterprise. When Balcerowicz left office, in 1992, the private sector was still a fuzzy gosling, but the Polish state would soon have for itself a golden goose. Where the free market liberal-democratic government had pursued hard policies toward the state sector, the social-democratic government displayed a softer touch. Instead of starving the state sector, they invested in it. Instead of punitive wage taxes, they gently introduced the personal income tax (PIT), easing the burden at first. They also extended the state's revenue claims to the new private 
sector. They did so in an incremental fashion, trying not to elicit too loud a hiss. The combination of these hard and soft strategies enabled the Polish state to expand its revenue base.

In Poland, as elsewhere, fiscal trends follow economic trends, and Poland's economy was the first in the post-communist world to start to grow again. Polish productivity increased every year between 1992 and 1998, marking seven consecutive years of growth for the first time since the 1970s (OECD, 1998, p. 13). By 1995, Poland's GDP returned to the pre-transition level; and, by 1998, its GDP was roughly 20 percent higher than the pre-transition level (OECD, January 2000, p. 25). Most notably, by 1995, new start-ups accounted for fifty percent of GDP, the highest rate in Eastern Europe (Aslund, 2002, Table 7.3). The growing economy, of course, meant that there was more to tax. The revenuepoor post-communist state introduced tax reforms designed to exploit two new sources of income: private businesses and employee households. By expanding the revenue base, the Polish state shored up the foundation of fiscal capacity - income. Total revenue receipts (including social security) as a percentage of GDP barely declined at all during the transition decade, from 42 percent in 1991 to 41 percent in 1998 (OECD, January 2000, Figure 29). Poland's ability to maintain steady income levels was a rare accomplishment among reforming post-communist states. (See Table 3.) But while these macro-indicators implied fiscal stability, they did not mean structural continuity. The Polish revenue base underwent fundamental change.

Table 3

Poland - Macroeconomic and fiscal trends, 1991-1997

(A) Economic growth, 1991-1997 (\% change on preceding year)

\begin{tabular}{|l|c|c|c|c|c|c|c|}
\hline & $\mathbf{1 9 9 1}$ & $\mathbf{1 9 9 2}$ & $\mathbf{1 9 9 3}$ & $\mathbf{1 9 9 4}$ & $\mathbf{1 9 9 5}$ & $\mathbf{1 9 9 6}$ & $\mathbf{1 9 9 7}$ \\
\hline Real GDP & -7.0 & 2.6 & 3.8 & 5.2 & 7.0 & 6.1 & 6.9 \\
\hline Capital investment & -4.5 & 2.8 & 2.9 & 9.2 & 18.5 & 21.6 & 21.9 \\
\hline Industrial output & -11.9 & 2.8 & 6.4 & 12.1 & 9.7 & 8.5 & 10.8 \\
\hline Agricultural output & -1.6 & -12.7 & 6.8 & -9.3 & 10.7 & 0.7 & 0.5 \\
\hline Consumption & 7.5 & 3.5 & 4.6 & 3.9 & 4.1 & 7.2 & 6.2 \\
\hline
\end{tabular}

(B) State budget, 1991-1997 (\% of GDP)

\begin{tabular}{|l|c|c|c|c|c|c|c|}
\hline & 1991 & 1991 & 1993 & 1994 & 1995 & 1996 & 1997 \\
\hline Revenue & 26.1 & 27.2 & 29.5 & 30 & 29.3 & 27.5 & 27 \\
\hline Expenditures & 29.9 & 33.2 & 32.3 & 32.7 & 31.9 & 30 & 28.3 \\
\hline Budget deficit & -3.8 & -6 & -2.8 & -2.7 & -2.6 & -2.5 & -1.3 \\
\hline
\end{tabular}

Sources: For Part A: World Economy Research Institute, 1998, p. 42 (Table 1). For Part B: OECD, 1997, p. 38, 40 (Figs. 14, 15). Budget figures do not include social security funds.

The main taxation trends of the 1990s were: from corporations to households; from public to private sector; from large to small firms; and from direct to indirect 
taxation. (See Table 4.) In 1990, corporate income tax (CIT) alone accounted for 43 percent of taxes collected to the state budget, but by 1994 that figure was reduced to little more than ten percent (OECD, 1994, p. 37). Meanwhile, household wealth was tapped to fill the void. Personal income tax accounted for one percent of taxes collected to the state budget in 1990, but shot up to more than 25 percent by the mid-1990s, and remained stable for the rest of the decade (Ibid.). ${ }^{5}$ Following a general transition pattern, economic activity increasingly shifted away from the public sector in the 1990s. Poland was particular in that economic growth was not led by privatized state enterprises, but by a rash of new start-up small businesses, where more than 60 percent of the workforce was found (OECD, 2001, p. 75). Whereas in 1990, households and transactions accounted for less than half of the total tax take, by mid-decade they made up two-thirds of all tax receipts (OECD, 1994, p. 37).

Table 4

Poland - Breakdown of tax revenue (as \% total state revenue)

\begin{tabular}{|l|c|c|c|c|c|c|c|c|}
\hline & $\mathbf{1 9 9 0}$ & $\mathbf{1 9 9 1}$ & $\mathbf{1 9 9 2}$ & $\mathbf{1 9 9 3}$ & $\mathbf{1 9 9 4}$ & $\mathbf{1 9 9 5}$ & $\mathbf{1 9 9 6}$ & $\mathbf{1 9 9 7}$ \\
\hline VAT/Excise taxes & 21 & 29 & 32 & 39 & 41 & 42 & 47 & 46 \\
\hline Corporate income tax & 43 & 24 & 21 & 17 & 15 & 13 & 11 & 11 \\
\hline Personal income tax & 1 & 2 & 21 & 23 & 25 & 25 & 24 & 25 \\
\hline Excess wage tax & 20 & 22 & 8 & 2 & 1 & - & - & - \\
\hline Other* & 14 & 23 & 20 & 19 & 17 & 20 & 18 & 18 \\
\hline
\end{tabular}

* The "other" category includes privatization revenues.

Sources: OECD, 1994, p. 37 (Diagram 5); OECD, 1997, p. 40 (Figure 15); OECD, 1998, p. 39 (Table 8).

The expanded revenue base provided income from two main sources: small businesses and wage-earner households. First, the Polish economy experienced a surge in petty capitalist activity. The new entrepreneurial private sector became the driving force in the recovery of the Polish economy. The private incentive policies of Finance Minister Balcerowicz encouraged hundreds of thousands of Poles to organize as small business entrepreneurs. Many of the new entrepreneurs benefited from an initial phase (usually three years) of income and transaction tax breaks to help them get started; by middecade, however, the small business sector began to contribute an increasingly larger share to the state's total tax take. Between 1993 and 1994, for example, the amount of tax income generated by small businesses to the state budget increased in real value by nearly 30 percent (Grabowski \& Smith, 1995, p. 111). At the start of the Polish transition, roughly 7500 state enterprises provided over 80 percent of total revenues (Mieszkowski et al., 1993, pp. 93-95). ${ }^{6}$ By 1993, however, the economy boasted over two million small and medium businesses, of which more than 1.8 million were registered with the tax authorities and making some form of payment to the state budget.

Second, the personal income of wage earners became a new revenue source for the state. Labor could not move its assets the way entrepreneurs could. The unfit tax administration may have had trouble keeping pace with the bookkeeping tricks of petty capitalists, but it had a much easier time catching up to the pay en- 
velopes of industrial workers and salaried employees, especially those in the more visible public sector (OECD, January 2000, p. 125). This was openly admitted by the government's vice minister for taxes, Witold Modzelewski, who expressed concern that an over-reliance on households would undermine civic morale to pay taxes (Polish News Bulletin, 20 May 1994). Employers were compelled to deduct the state's revenue claim from employee paychecks, making it difficult for workers to escape the notice of tax officials, at least without management's cooperation. But unlike the punitive popiwek payroll tax that cut into enterprise profits, the new personal income tax (PIT) did not unify the economic interests of managers and workers. The implementation of the PIT in 1992 had an immediate effect on the revenue base. The share of PIT in the state's total tax take went from about one percent in 1991 to 20 percent in 1992 (OECD, 2000, pp. 116, 121-123). The number of individuals making PIT declarations to the state's tax authorities rose quickly. PIT accounted for nearly a quarter of total revenues collected in the mid-1990s.

The dispersion of economic activity from large industrial conglomerates of several thousand workers to small retail trade and service businesses of ten or less employees dramatically remolded the structure of the revenue base. The amounts of revenue available from any small entrepreneur or individual wage earner were miniscule, but when amassed these two groups offered potentially significant income sources. Because the state was able to capture an adequate share of this wealth, state finances remained relatively stable. The deficit of the consolidated government budget, which approached six percent in 1992, was cut by more than half, remaining less than three percent between 1995 and 1998 (OECD, 1994, Table 8; OECD, 1998, Table 7). ${ }^{7}$

Nonetheless, the state-labor revenue bargain put pressure on state finances. One part of the bargain was to take care of public employees who departed the active workforce. The social-democratic government increased the state's social commitments to the unemployed, retired, and disabled. In 1990, for example, the state subsidized 7 million pensioners (retired and disabled), but in 1998 the number rose to 9.5 million. Moreover, the value of the pension increased from 53 percent of the average public wage in 1989 to 67 percent in 1998 (Lenain \& Bartoszuk, 2000, p. 5). Significantly, nearly 15 percent of Poland's GDP was invested into pensions - twice as much as the OECD average. The government's strategy of easing the economic hardships of structural reform on displaced workers served the political interests of the social democrats, but not the fiscal interests of the post-communist state. Budgetary expenditures in 1997 amounted to 45 percent of Poland's GDP, comparable to its prosperous neighbor Germany and more than 5 percent higher than the OECD average; Poland's total revenue take, however, was only 40 percent (Ibid, figures. 2, 4). The cost of these commitments overextended the state budget. Meanwhile, another part of the bargain was the use of tax exemptions to subsidize wage-earner households. But the loss of income from this strategy was not insignificant: the percentage of lost PIT revenue was a whopping 24 percent in 1996,15 percent in 1997, and 14 percent in 1998. The PIT rate brackets ranged from an upper 40 to a lower 19 percent, but with all the exemptions the real PIT average tax rate for the whole economy in 1998 fell to 12.5 percent (OECD, 2000, p. 127).

Even with an expanded revenue base, the Polish government still had to deal with deficit financing. To make up the difference between expenses and 
income, the government returned to credit markets. Poland began the transition in debt and in default, but quickly acted to straighten out its credit situation. First, the free-market government renegotiated outstanding debts to the West, while the social-democratic government renegotiated outstanding debts to the East. One of the advantages of appointing Balcerowicz as finance minister was that he was a true-believing capitalist and conversant in the manners of the international financiers. President Lech Walesa's first visit abroad as head of state was to the United States to appeal to have Poland's debt obligations reduced by eighty percent. The rescheduling of Polish debt to the West removed a huge constraint on the first post-communist government, enabling it to introduce radical reform in the midst of fiscal crisis. In 1994, Poland reached agreement with the London Club, which forgave nearly half of Poland's $\$ 14$ billion in debt to Western commercial banks (World Economy Research Institute, 1998, p. 170). Table 5 shows how by mid-decade the heavy burden on state finances was significantly eased as a result of Poland's successful petitions for foreign debt relief. The tax system generated sufficient income for the state to make regular payments for rescheduled debts. As a result, Poland's credit rating was raised, and new lines of credit were opened, which covered budget deficits.

Table 5

Poland's foreign debt burden

\begin{tabular}{|l|c|c|c|c|c|c|c|c|}
\hline & $\mathbf{1 9 9 0}$ & $\mathbf{1 9 9 1}$ & $\mathbf{1 9 9 2}$ & $\mathbf{1 9 9 3}$ & $\mathbf{1 9 9 4}$ & $\mathbf{1 9 9 5}$ & $\mathbf{1 9 9 6}$ & $\mathbf{1 9 9 7}$ \\
\hline Total debt (\$bln) & 48.5 & 48.4 & 47.0 & 47.2 & 42.1 & 43.9 & 40.5 & 38.0 \\
\hline Debt service (\% GDP) & 35.9 & 26.6 & 33.3 & 28.8 & 14.7 & 5.3 & 4.6 & 3.7 \\
\hline - interest & 42.6 & 42.4 & 13.2 & 10.2 & 11.4 & 2.4 & 4.2 & 2.8 \\
\hline - principal &
\end{tabular}

Source: World Economy Research Institute, 1998, p. 139 (Table 30).

With steady income and credit restored, the Polish state did not have to take any drastic devaluations of currency. The government pursued a policy of gradual disinflation. By mid-decade, the zloty was stable. Moderate increases in the money supply were consistent with economic growth trends. (See Table 6.)

Table 6

Currency trends, 1991-1997 (\% change from previous year)

\begin{tabular}{|l|c|c|c|c|c|c|c|}
\hline & $\mathbf{1 9 9 1}$ & $\mathbf{1 9 9 2}$ & $\mathbf{1 9 9 3}$ & $\mathbf{1 9 9 4}$ & $\mathbf{1 9 9 5}$ & $\mathbf{1 9 9 6}$ & $\mathbf{1 9 9 7}$ \\
\hline Inflation & 47 & 43 & 35.3 & 32.2 & 27.8 & 19.9 & 14.9 \\
\hline Money supply & 75 & 56.6 & 34.8 & 39.3 & 34.8 & 29.1 & 28.8 \\
\hline
\end{tabular}

Source: World Economy Research Institute, 1998, p. 100 (Table 15).

By the late 1990s, Poland's transitional tax regime was in place. It was flawed, it was contested, and it was bringing in enough revenue to keep the post- 
communist state operating with only minimal deficits. The compliance strategy of legalistic consent worked sufficiently well for the post-communist state to strengthen fiscal capacity and maintain social welfare commitments.

\section{State fiscal capacity and the 1998 financial crisis}

When the financial crisis of emerging market economies reached Eastern Europe, in 1998, the Polish state remained solvent. The state's resilience to the capital crisis was not because of good fortune, but good policy, enacted by Poland's post-communist elites, who in the late 1990s came to consensus on prudent management of state finances.

In 1997, Poland benefited from elite consensus, with negotiation and promulgation of a post-communist constitution. In January, a draft constitution outlining a mixed system, in which the balance of power was tipped in favor of parliament, was introduced for public debate. The draft was delivered by a special parliamentary commission, which had been working on the document for nearly three years. The commission comprised the four major political groupings in the 1993 Sejm: social democrats, free-market liberal democrats, peasant party, and trade union bloc. To become the law of the land, the draft had to be debated, amended and accepted by both houses of parliament, and then approved in a nationwide referendum. But Solidarity and the Catholic Church raised objections: the former, still obsessed with punishing former communists and collaborators, wanted explicit rejection of the old regime; and, the latter, still concerned with preventing a secular state, wanted explicit recognition of a higher power. They threatened to obstruct the process unless their demands were met. Negotiations were hastily convened, as political leaders urged compromise. Sejm Speaker Josef Zych made a nationally televised plea to rally popular support for the draft constitution (Rzeczpospolita, 30 January 1997, p. 2). Prime Minister Wlodimierz Cimoszewicz stressed that the draft reflected the willingness of partisan political actors to find common agreement even when divided by particular interests and others should do the same (Nowa Europa, 12 February 1997, p. 8). And, President Aleksander Kwasniewski went further: "The draft does not correspond 100 percent to a single author, because this work rests on many ideas and on compromise, which is the great virtue of the constitution" (Gazeta Wyborcza, 3 March 1997, p. 3). Consensus prevailed; the challengers were appeased with modest concessions. In July 1997, Poland at last had a post-communist constitution.

The constitution not only delineated a division of power in the post-communist state, it also provided a legal framework for the management of state finances. Political party leaders agreed on the need to establish a set of formal institutional constraints on fiscal policy, which went into law in the constitution and in several follow-up financial reform acts. The adoption of fiscal institutional reform formalized the basically sound fiscal practices of the social democrat government. And when the social democrats strayed too far, the free- market liberal democrats in parliamentary opposition were quick to mobilize a political response to check excessive taxation or extravagant spending. While the con- 
stitutional codification of fiscal prudence reflected the concerns of influential domestic political actors, it also made for a nice gesture to skeptical EU technocrats about Poland's commitment to fiscal responsibility. The new measures were intended to depoliticize the fiscal policy process as well as to limit the options of state financial policymakers.

First, fiscal institutional reform restricted the influence of political actors and enhanced the role of policy experts in the fiscal policy process. The constitution curtailed the powers of the president, taking away the presidential veto over the state budget. The parliament, meanwhile, was no longer allowed to amend monetary policy. The powers of the National Bank were scaled back as well, as the constitution forbade it from lending capital to finance budget deficits. Real responsibility for the national currency was entrusted to a new Monetary Policy Council (MPC), which oversaw the implementation of monetary policy. The MPC was chaired by the head of the National Bank, and composed of nine financial experts, three each nominated by the president, the Sejm and the Senate. To further insulate fiscal policy from politics, MPC members served fixed six-year terms, subject to recall only under extraordinary circumstances. ${ }^{8}$

Second, new restrictions were placed on budgetary policy. The range of options for financing the state budget were explicitly defined and limited: the government must rely on income, not currency or credit. It was not a strict "payas-you-go" policy, but it encouraged a more cautious approach toward the expenditure side of the state ledger. The new constitution erected a debt ceiling for state finances at 60 percent of GDP. In May 1998, more elaborate rules were announced by which a series of corrective measures and spending freezes would go into effect if the debt exceeded 50 percent of tax income. The government was no longer permitted to include privatization sales as budgetary revenue, since these were one time transactions and not regular income. Meanwhile, further down the administrative chain, tight controls were placed on the spending and borrowing practices of local governments (OECD, 2001, pp. 52, 53). Finally, in a related act, the financial reform package also included a more comprehensive regulatory regime for the commercial banking sector.

The big test for Polish state finances came in 1998, when the capital crisis of emerging market economies spread from Asia to Eastern Europe. The first smallish tremors were felt in January: Korean investors pulled out of a multimillion dollar joint venture deal and the Warsaw Stock Exchange dropped five percent of its value (Gazeta Wyborcza, 29 January 1998, p. 21). The MPC was forced to make a minor devaluation of the zloty; the currency corrective calmed foreign investors who returned in February. In May, an official from the European Bank for Reconstruction and Development (EBRD) praised Poland as the only emerging market economy in Eastern Europe unscathed by the Asian crisis; and, in June, Merrill Lynch touted Polish short-term treasury bills as an attractive and safe foreign investment opportunity (Rzeczpospolita 12 May 1998; Prawo i gospodarka 3 June 1998). But in August, the resounding fiscal crash of post-communist neighbor Russia sent shockwaves through Poland's transition economy. 
Political leaders from across party lines (social-democratic president, Solidarity bloc prime minister, and free-market liberal-democratic finance minister) quickly found common purpose to prevent a panic. On television, in the press, before business audiences, to whoever would listen, they talked up the economy's underlying strength and played down investors' rising fears (Rzeczpospolita 22-23 August 1998, p. 7). They consulted on strategy with international financial organizations in the West, and coordinated tactics with fellow post-communist governments in the East. They renegotiated the 1999 state budget, cutting back previously planned spending increases and lowering revenue projections. Even if basic macro-indicators were sound, political actors on all sides recognized that the psychology of investors could rattle the foundations of state finance and threaten fiscal crisis.

Despite the reassurances of a united political front, the initial response of foreign capital was to flee the Polish economy. On the day after the Russian crash, the Ministry of Finance held an auction for foreign buyers of short-term debt treasury bills. Nobody showed up (Polish News Bulletin, 18 August 1998). In the fortnight that followed, foreign investors cashed out over one billion dollars from the financial system. The accumulated value of traded shares on the Warsaw Stock Exchange tumbled its way down to a 30 percent loss. Under pressure to adjust the exchange rate again, the MPC authorized another minor devaluation of the zloty. The currency devaluation was meant to help Polish producers, whose second largest export market was Russia (Rzeczpospolita, 18 August 1998, p. 1; 27 August 1998, p. 16). Poland's foreign trade deficit leapt from $\$ 250$ million in August to $\$ 1.5$ billion in September. A nationwide survey conducted a month after the Russian crash indicated persisting public anxiety, as more than 70 percent of Poles expressed fear that the international financial crisis would hit them next (CBOS Polish Public Opinion, October 1998).

But the political campaign to convince foreign capital to stay put was not a baseless appeal. Polish state finances really were in good shape. By 1998, Poland was a leader among post-communist states in building fiscal capacity - income, credit, currency. First, Polish state coffers were regularly replenished from the new sources of income. While income as a percentage of GDP declined one point (from 42 to 41 percent) from the previous year, GDP was growing, so the state's total revenue take in 1998 actually increased by 14 percent from the previous year (from 197 billion zloty to 225 billion zloty) (OECD, 2000, Table 6). The 1998 budget deficit remained a manageable 2.5 percent, although the next year it climbed back over three percent. Most importantly, Polish businesses remained profitable. Some producers, especially in agriculture, were hit hard by the loss of the Russian market; however, Russia accounted for less than ten percent of exports. By 1998, Poland's trade relations were reoriented to the West, and thus were not adversely affected by the capital crisis to the East. Germany had become Poland's largest trading partner (Prawo i gospodarka, 18 August 1998, p. 1).

Second, with sufficient income sources at hand, Poland was not overextended in credit when things fell apart all around them. State finances were no longer constrained by crippling foreign debt, most of which was earlier renegotiated and some of which was now retired. The cost of debt service to the 
budget steadily dropped, as shown in Table 5. Even if foreign creditors were now to leave en masse, the state was not dependent on their capital. By 1998, Polish households, enticed by a personal income tax deduction, were the main purchasers of government bonds (OECD, 2004, p. 84). Foreign investors owned only 8 percent of short-term Treasury bills and 21 percent of long-term bonds (Rzeczpospolita 22-23 August 1998, p. 7). Maybe foreigner investors did not rush to buy MinFin's latest T-bill offerings, but they did not cash out the T-bills they were holding either. As indication of the state's manageable credit situation, interest rates on short-term debt remained moderate and stable throughout the summer and fall of 1998, suggesting relatively low risk (Rzeczpospolita 17 July 1998 , p. 1). Third, since the state was not overextended on credit, it was not forced to undercut the zloty. In August, the MPC approved only a small currency devaluation to help Polish exporters. By mid-September, the head of the central bank, Hanna Gronkiewicz-Waltz, reported that the financial system was still in good shape and that the zloty had withstood the crisis, retained its value, and was stable Rzeczpospolita 12-13 September 1998, p. 8). Indeed, by the year's end, the value of the zloty appreciated.

The fiscal capacity of the post-communist Polish state, in the 1990s, was sufficiently strengthened to survive the capital crisis of the emerging market economies. Poland did not experience a flight of foreign investment (Warsaw Voice, 1998, pp. 22, 23). State fiscal managers were not forced to default on debt obligations, nor did they undertake inflationary currency devaluation. Even though business activity stuttered, the economy still registered nearly five percent growth for the year. And people paid taxes; maybe not all that was owed, but enough to keep the state solvent. Underlying the fiscal capacity of the Polish state was a transitional tax regime, which provided reliable sources of income, and an elite consensus, which reinforced responsible fiscal management.

\section{State fiscal capacity and the 2008 financial crisis}

In 1998, Poland had good fiscal fortune because it had good fiscal policy. But the transition economy did not go unscathed. For the next year or so, there was noticeably less investment capital, higher borrowing costs, and lower output levels. In the second half of the 1990s, state finances were sustained by strong economic growth; but in the early 2000s, an economic slowdown threatened to weaken fiscal capacity. At that time, the inherent tensions between political and fiscal interests, found within the state-labor revenue bargain, could no longer remain suppressed. The costs of maintaining the revenue bargain, particularly the use of tax exemptions as social subsidies, was cutting into the state's budgetary income as well as violating the EU's conditional demands. By mid-decade, however, the economy was again in good form, and the state again claimed a sufficient share of society's wealth. Poland benefited from both capable fiscal management and dynamic economic growth. In 2008, when the international financial crisis struck, state fiscal capacity once again absorbed the blow.

As the economy goes, so goes state finances. The second decade of the Polish transition brought continued economic growth, though it did not start out 
that way. When economic growth stuttered, state budget deficits ballooned past 5 percent in early 2000s. But the economic slowdown proved short-lived, by mid-decade Poland boasted one of Europe's strongest growth rates. Table 7 provides an overview of the Polish economic and fiscal trends in the second transition decade.

Table 7

Poland - Macroeconomic and fiscal trends, 2001-2009

(A) Economic growth, 2001-2009 (\% change on preceding year)

\begin{tabular}{|l|c|c|c|c|c|c|c|c|c|c|}
\hline & $\mathbf{2 0 0 0}$ & $\mathbf{2 0 0 1}$ & $\mathbf{2 0 0 2}$ & $\mathbf{2 0 0 3}$ & $\mathbf{2 0 0 4}$ & $\mathbf{2 0 0 5}$ & $\mathbf{2 0 0 6}$ & $\mathbf{2 0 0 7}$ & $\mathbf{2 0 0 8}$ & $\mathbf{2 0 0 9}$ \\
\hline Real GDP & 4.3 & 1.2 & 1.4 & 3.9 & 5.3 & 3.6 & 6.2 & 6.8 & 5.1 & 1.7 \\
\hline Investment & 3.9 & -13.4 & -7.2 & 3.3 & 14.7 & 1.4 & 16.1 & 24.3 & 4.0 & -13.4 \\
\hline Industrial output & 6.3 & -0.8 & -0.5 & 7.8 & 10.5 & 3.5 & 10.0 & 10.1 & 6.8 & -0.3 \\
\hline Consumption & 2.9 & 2.3 & 3.0 & 2.7 & 4.3 & 2.7 & 5.2 & 4.6 & 6.1 & 2.0 \\
\hline
\end{tabular}

(B) Consolidated state budget, 2001-2009 (\% of GDP)

\begin{tabular}{|l|c|c|c|c|c|c|c|c|c|c|}
\hline & $\mathbf{2 0 0 0}$ & $\mathbf{2 0 0 1}$ & $\mathbf{2 0 0 2}$ & $\mathbf{2 0 0 3}$ & $\mathbf{2 0 0 4}$ & $\mathbf{2 0 0 5}$ & $\mathbf{2 0 0 6}$ & $\mathbf{2 0 0 7}$ & $\mathbf{2 0 0 8}$ & $\mathbf{2 0 0 9}$ \\
\hline Revenue & 36.5 & 37.1 & 36.7 & 38.6 & 38.6 & 39.1 & 39.6 & 41.3 & 40.3 & 40.2 \\
\hline Expenses & 39.3 & 42.0 & 42.5 & 43.8 & 43.2 & 41.7 & 41.7 & 41.2 & 41.9 & 44.0 \\
\hline Deficit & -2.8 & -4.9 & -5.7 & -5.2 & -4.5 & -2.6 & -2.1 & +0.1 & -1.6 & -3.8 \\
\hline
\end{tabular}

Sources: Part A: Glawny urzand statystyczny (GUS) (Main Statistical Office), 2010, p. 696 (Table 575); Part B: ibid., p. 642 (Table 536).

When Wall Street popped its bubble, Poland's government was in the hands of market liberals. Prime Minister Donald Tusk entrusted state finances to Jacek Rostowski, who turned out to be another strong-willed and most capable finance minister. His first official act was to have the portraits of communistera finance ministers removed from finance ministry and consigned to a museum (Dziennik 10-11 May 2008, pp. 20, 21). Rostowski's resume impressed: the British-born and western-trained economics professor founded the influential Polish think-tank CASE (Center for Social and Economic Research), worked with Balcerowicz at the Ministry of Finance and the National Bank, and advised the Russian government when it undertook liberalizing fiscal reforms. His appointment, however, was anything but well-received. Still smarting from electoral defeat, the conservative populists questioned Rostowski's patriotic credentials: How can a foreigner who does not pay taxes in Poland possibly manage MinFin? From the ranks of market liberals, Rostowski was assailed by disgruntled rivals for not being a real party member or an authentic neo-liberal. ${ }^{9}$ Former finance minister Zila Gilowska ridiculed Rostowski for not holding a doctorate degree (Polityka, 23 May 2008, pp. 16, 18). Unlike previous finance ministers, Rostowski appeared to lack political clout, since he was not named deputy prime minister. What he did have, however, was the full confidence of his friend, the prime minister. 
Rostowski came to office with a mostly liberal policy agenda: controlling social spending, trimming tax rates, deregulating the business sector, and joining the Euro-zone. He was a genuine fiscal conservative, not a knee-jerk free marketeer. Although Rostowski pushed for personal and corporate income tax cuts, he was careful not to disrupt revenue flow to the state budget. ${ }^{10}$ First, he removed the flat tax reform from the policy agenda, citing a need to act both fiscally and socially responsibly. Second, he opposed the elimination of capital gains tax, arguing that it was the most effective means to assure that Poland's very rich pay taxes. Third, he supported the "50+" initiative, which promised incrementally higher pension rates for each year that a worker stays on past retirement. This policy based in individual-incentive market economics was, in fact, meant to help sustain the personal income tax (PIT) as a revenue source. Fourth, he seized income-generating ventures, existing discreetly within state officialdom. In particular, he targeted for privatization a chain of hotels run by the Military Property Agency. When the Ministry of National Defense protested, he caustically countered that liberating the military from the tourist trade would not likely sacrifice national security. Finally, he refused to lower sales taxes to encourage consumption, again, because of the need to maintain budgetary income. This last issue almost forced his resignation.

Poland's conservative populists did not care much for the finance minister, and the feeling was mutual. Rostowski was openly derisive of the Kaczynski brothers' chauvinistic rhetoric, saying that it harmed Poland's standing in Europe. ${ }^{11}$ The international financial crisis provided the opportunity for Rostowski's critics to act. In June 2008, Jaroslaw Kaczynski, leader of the Law and Justice party in the Sejm, insisted that the government cut the petrol tax; Rostowski refused even to consider the proposal, saying the measure would only benefit the fuel industry (Rzeczpospolita 13 June 2008, p. 4). Kaczynski threatened that if the tax was not cut, he would initiate a no-confidence vote (Wall Street Journal Polska 31 May - 1 June 2008, p. 3). (The fact that it had been Kaczynski's government that raised the petrol excise tax was omitted from the populist rhetorical barrage.) Neither side budged. The populists went ahead with the no-confidence vote in the Sejm, which Rostowski survived by a count of 235 to 150 (Gazeta Wyborcza 14-15 June 2008, p. 37). A year later, the Kaczynskis tried again. Rostowski's 2009 budget was based on an overly optimistic growth assessment and had to be readjusted several times. This led to charges of amateurism and mismanagement. The Law and Justice deputy head of the Sejm public finance committee suggested that Rostowski's budget read more like "science fiction" than state finance (Gazeta Wyborcza 23 May 2009). The conservative populists instigated yet another no-confidence vote, this time with support from the social democrats. Rostowski survived yet again, though by a lesser margin, 223 to 193 (Polish News Bulletin 26 June 2009).

At the start of 2009, Rostowski was pilloried by the Polish parliament; by the end of 2009, he was hailed across Europe as "Finance Minister of the Year." ${ }^{2}$ Unlike the rest of Europe, in Poland, Rostowski refused to shed market liberalism for "crisis-Keynesianism." To begin, he insisted that the real economy was strong, and that it would withstand the worst effects of the financial crisis. Next, 
when the economy began to slow, he resisted using state funds to stimulate activity, citing the detrimental long-term effect of large budget deficits. Finally, he shot down all parliamentary proposals for populist tax breaks. These policies incurred rancor and ridicule, but eventually were vindicated. In 2009, Poland was the only country in Europe to escape recession, scoring nearly two percent positive growth. Rostowski may have overestimated the strength of the Polish economy, but not by much. Economic activity slowed, but did not stop; credit became tighter, but banks did not fail. In 2010, the World Economic Forum promoted Poland to 39th place on its annual Global Competitiveness Index, stating: "This significant improvement for a second year in a row reflects the country's relatively stronger resistance to the economic crisis as a result of more prudent economic policies and its growing domestic market size." ${ }^{13}$

Though unwilling to make dramatic public gestures to cue private actors, Rostowski was keenly aware of the effect that state fiscal capacity had on the economy as a whole. When the stability and credibility of state finances were threatened, he did not hesitate to intervene. ${ }^{14}$ To compensate for income lost from slower growth rates, Rostowski moved to privatize more state-operated entities, including power companies and the Warsaw Stock Exchange. When a run on the currency began, he used the government's special savings to buy up zlotys. The daring move succeeded to restore confidence in the currency, saving it from freefall. The value of the zloty fluctuated, before settling down at a moderately lower value, which, in turn, benefited domestic producers. Unlike its neighbors, Poland's economy experienced neither a sharp rise in inflation, nor a major drop in household consumption. Despite these steps, the budget deficit still increased, surpassing the EU-mandated three percent ceiling. The government made up the difference through the successful issuing of longterm, low-interest bonds and by securing a generous credit line from the EU. In early 2010, Rostowski announced a "financial consolidation package," which stated fiscal priorities for the next couple years: to reduce the deficit below three percent, without raising tax rates; and, to move Poland into the Euro-zone.

Poland was in an advantageous position to survive the 2008 international financial crisis because of the structure of its economy, which was not overly dependent on foreign capital and trade; and the strength of fiscal capacity, which was able to absorb the external shock. Poland's institutions of state finance, The National Bank, the Monetary Policy Committee, and the Ministry of Finance provided a coordinated and flexible response that kept the Polish domestic economy mostly insulated from the international financial crisis. Underlying state fiscal capacity was the ability of the state to assure a steady flow of income. Because of this, even when the budget deficit rose, the state was able to gain access to credit at manageable interest rates and did not have to resort to currency devaluation. This was all possible because state fiscal capacity rested on a sufficient and reliable flow of income, which was the result of Poland's "legalistic consent" tax regime.

When tested by international financial crisis, the Polish state fared well. Poland's tax regime provided sufficient revenue to establish a secure fiscal foundation for the new state. The revenue base expanded to include a share of the 
wealth of wage earning households and enterprising small businesses. By creating new sources of income, the Polish state strengthened fiscal capacity during the transition decade and beyond. When international capital crises moved across Eastern Europe in 1998 and 2008, Polish state finances held firm. Because of the steady stream of income flowing into the state treasury, Poland's currency and credit remained stable. Underlying Polish state finance was a tax regime based on "legalistic consent."

By post-communist standards, the Polish case of fiscal reform was a smashing success. The factors that best explain this outcome are economic and political. First, social scientists and policymakers have long debated whether the path to economic prosperity lies in radical free market reforms or gradualist social market reforms. The Polish case shows that this is a false choice. Poland's impressive economic recovery would not have been possible without the introduction of generous material incentives aimed at individuals to take the initiative to leave the state managed economy to start over in the private sector. The social dynamic that boosted Polish economic growth and steadied state finances was revenue generated by the new small business sector. But unbridled "shock therapy" would have torn asunder any semblance of a social contract. It was the social-democratic policy of regulated markets, investment in the public sector, and social protection that skillfully restored political peace without quashing the nascent private sector.

Second, Polish success benefited from a political condition - elite consensus. Despite the residuals of bitterness often displayed in politics, Polish elites remained united on the basic contours of the post-communist future: Poland should be a democracy, should have a market economy, and should be part of Europe. When conflicts arose that threatened to become paralyzing crises, Polish elites, particularly the social democrats and liberal democrats, were capable of sitting down and reaching compromise solutions. An elite consensus was evident is the handling of state finances, perhaps inspired by memories of communist Poland's debilitating fiscal crises. By the late 1990s, a set of policies, concerning debt, borrowing and currency, was enacted to insulate state finances from partisan politics. These policies did not put an end to debate over taxes, social subsidies and the like, but they did define broad consensual parameters over the prudent management of state finances. These economic and political factors help to distinguish the Polish case from so many of its post-communist East European peers. They are the foundation upon which Polish state finances were successfully reconstructed. 


\section{REFERENCES}

1. Aslund, A. (2002). Building capitalism. Cambridge: Cambridge University Press.

2. Belka, M., Krajewska, A., Krajewski, S. \& Santos, A. (1993). Country overview study: Poland. Eastern European Economics, vol. 31, n. 5, pp. 19-62.

3. Borodo, A. (2000). Finanse publiczne (Public finance), 3d ed. Warsaw: Wydawnictwo prawnice.

4. Bratkowski, A. (1997). Macroeconomic performance. Russian and East European Finance and Trade, vol. 33, n. 6, pp. 8-30.

5. Crombrugghe, A. de, \& Lipton, D. (1994). The government budget and economic performance in Poland. (In: The transition in Eastern Europe, Vol. 2. Restructuring, eds. O.J. Blanchard, K.A. Froot \& J.D. Sachs). Chicago: University of Chicago Press.

6. Glawny urzand statystyczny (GUS) (Main Statistical Office), 2010, Rocznik statystyczny Rzeczypospolitej Polskiej, 2009 (Statistical Yearbook of the Polish Republic), Warsaw. Available: http://www.stat.gov.pl/gus/5207_ENG_HTML.htm (accessed: 15 June, 2015)

7. Grabowski, M. \& Smith, S. (1995). The taxation of entrepreneurial income in a transition economy: Issues raised by the experience of Poland. (In: Tax and benefit reform in Central and Eastern Europe, ed. D.M.G. Newbery). London: Centre for Economic Policy Research, pp. 95-114.

8. Lenain, P. \& Bartoszuk, L. (2000). The Polish Tax Reform. OECD Economics Department Working Papers, n. 234. Paris: Organization for Economic Co-operation and Development.

9. Mieszkowski, P., Bolkowiak, I., Lubick, D. \& Sochacka-Krysiak, H. (1993). Tax Reform. (In: Stabilization and structural adjustment in Poland, eds. H. Kierzkowski, M. Okolski, \& S. Wellisz, eds.). London: Routledge, pp. 92-111.

10. OECD (1992, 1994, 1997, 1998, January 2000, 2000, 2001). OECD Economic Survey: Poland. Paris: Organization for Economic Co-operation and Development.

11. Rosati, D. (1998). Polska droga do rynku (The Polish road to the market). Warsaw: Polskie Wydawnictwo Ekonomiczne.

12. Warsaw Voice (1998). The Warsaw voice: Business and economy yearbook, Warsaw.

13. Wellisz, S., Kierzkowski, H. \& Okolski, S. (1993). The Polish economy 19891991. (In: Stabilization and structural adjustment in Poland, eds. H. Kierzkowski, M. Okolski, \& S. Wellisz). London: Routledge, pp. 29-63.

14. World Economy Research Institute (1992). Poland: International Economic Report, 1991/92, Warsaw School of Economics, Warsaw.

15. World Economy Research Institute (1998). Polish International Economic Report, 1997/98, Warsaw School of Economics, Warsaw. 


\section{NOTES}

1 From 1992 to1996, Witold Modzelewski, who was connected to Finance Minister Grzegorz Kolodko, was the vice minister for taxes; subsequently he was tasked with the founding of a new National Fiscal Academy. From 1992 to 1998, Waldemar Manugiewicz, who was connected to the social democrats, served as vice minister, overseeing the introduction of the value-added tax (VAT) reform, heading the fiscal control department, and serving as undersecretary for taxes.

See interview with Jerzy Osiatynski, Polish News Bulletin, 3 September 1992.

See interview with Andrzej Zelechowski, MinFin's tax department head, in Gazeta Wyborcza, 20 August 1993.

The dividend tax was another of Balcerowicz's punitive taxes on the state sector.

These figures are for total tax take, and did not include social security contributions.

Total tax revenues include direct and indirect taxes on the corporate sector as well as social insurance taxes for the year 1988.

7 The deficit numbers sometimes appear even lower, when privatization revenues are included in the calculations.

Author's interview with Stanislaw Owsiak, member of the Monetary Policy Council, in Krakow, 6 July 2005.

9 Rostowski's main nemeses were: from the conservative populist Law and Justice party, the deputy-head of the Sejm's finance committee, Aleksandra Natalli-Swiat; and, from the market-liberal Civic Platform party, Zbigniew Clebowski, who fancied himself as finance minister and made the elimination of the capital gains tax his personal mission.

10 Rostowski's policy agenda is summarized in an interview in Polityka, 23 May 2008, pp. 16, 18.

11 Ibid. Lech Kaczynski was president and his twin brother, Jaroslaw Kaczynski, was prime minister.

12 The honor was bestowed by The Banker, a subsidiary publication of The Financial Times.

13 See the World Economic Forum website: http://www.gowarsaw.eu/en/news/polandadvances-to-39th-in-world-economic-forums-competitiveness.

14 See the interview with Rostowski in The Financial Times, 23 October 2009. 